\title{
City residents, scientists and policy-makers: power in co-producing knowledge
}

\author{
Kareem Buyana ${ }^{1 *}$, Jacqueline Walubwa ${ }^{2}$, Paul Mukwaya ${ }^{1}$, Shuaib Lwasa ${ }^{1}$ and Samuel Owuor ${ }^{2}$
}

\author{
*Correspondence: kbuyana@gmail. \\ com \\ ${ }^{1}$ Urban Action Lab of Makerere \\ University Uganda, Department of \\ Geography, Geo-informatics and \\ Climatic Sciences, College of \\ Agricultural and Environmental \\ Sciences, University Road, CHUSS \\ Building, South Wing Ground Floor, \\ P.O Box 7062, Kampala, Uganda \\ Full list of author information is \\ available at the end of the article
}

\begin{abstract}
The need to merge scientific with societal knowledge in addressing global sustainability challenges has deepened research on a methodology known as coproducing knowledge. It differs from participatory approaches by holding potential for solution-oriented research through sustained relationships with actors across disciplines and sectors. Although there is growing recognition that power shapes interactions in co-producing knowledge, few studies have empirically grounded articulations of power in the context of urban sustainability. This paper draws on case study projects in Africa to discern the forms of power that are navigated by actors when co-producing locally grounded knowledge and solutions for urban sustainability. The projects include: localizing norms on sustainable energy in Kampala city Uganda; confronting coastal vulnerability in Durban South Africa; and upgrading informal settlements in Stellenbosch South Africa. The forms of power across the projects are: expert power by academics; statutory power for policymakers; and the power of locally-embedded knowledge by city residents. Navigating these forms of power is possible, if boundary objects are used in dialogues on scalable solutions to sustainability challenges. The boundary objects in the case studies are: briquettes from organic waste as alternative cooking energy for households in Kampala; a locally-appropriate costal vulnerability index for visioning sustainable climate action in Durban; and an improved Shack dwelling for improving living conditions in Stellenbosch. These boundary objects interrupted the reproduction of unequal power relations, while demonstrating how hierarchies in coproducing knowledge can be flattened.
\end{abstract}

Keywords: Power dynamics, Co-production, Sustainability, Boundary objects, Cities, Africa

\section{Science highlights}

- Co-production holds potential for solution-oriented research through sustained relationships with actors across disciplines and sectors.

- There is growing recognition that power dynamics are at the core of co-producing knowledge, but few studies have empirically grounded articulations of power in the context of urban sustainability. 
- The paper discerns the forms of power that are navigated when co-producing locally grounded knowledge and solutions for urban sustainability challenges.

- The forms of power are: i) expert power held by academics; ii) statutory power for the policy-makers; and iii) the power of locally-embedded knowledge by residents.

- Navigating the three forms of power is possible, if boundary objects are used in envisioning, negotiating, learning and experimenting alternative actions for sustainable urban transformations.

\section{Policy and practice recommendations}

- Academics and non-academics can jointly produce knowledge on sustainable cities by seizing the learning and scale-up potential of micro-level innovations in local communities.

- Unequal power relations between academics and non-academics can limit the potential for joint production of knowledge.

- Boundary objects, such as energy briquettes and the improved Shack in this paper, can interrupt unequal power relations in collaborative knowledge production.

\section{Introduction}

The production of knowledge on sustainable urban development is no longer a sphere for a particular science discipline (Bai et al. 2010; Kasperson and Berberian 2011). Universities are increasingly being called upon to institute mechanisms for breaching silos across disciplines, and reach out to policy-makers and local communities to form partnerships that can build a foundation for collaborative research on sustainable urban development (Mori et al. 2015; Dentoni and Bitzer 2015; Ziervogel et al. 2016; Van der Hel 2016; Bremer et al. 2019; Rodríguez et al. 2019; Matthews and Papoulias 2019). It is for this reason that a methodology known as co-producing knowledge has become key in merging scientific with societal knowledge to address global urban sustainability challenges like climate change, inequality and disease outbreaks. The roles that academic and non-academic actors take on in co-producing knowledge are not at all times congruent with their expertise, but rather such roles are continuously shaped by formal and informal relationships that emerge from negotiations, learning and experimenting sustainability solutions (Wittmayer and Schäpke 2014; Loorbach et al. 2017). As this methodological position continues to uncover within sustainability sciences, the relevance and application of co-producing knowledge is increasingly becoming heterogeneous. For some, the logical principles and steps for problem-definition are key, like Hadorn et al. (2008), Lang et al. (2012) and Pohl et al. (2017), who build on case studies across the globe to present methods for problem structuring, problem investigation and bringing results to fruition. To others, contextual variations matter, like Van Breda and Swilling (2018) as well as Buyana (2019), who offer emergent transdisciplinary research (ETDR) as the organizational arrangement for nurturing synergies amongst scientists, policy-makers and local residents.

Since co-producing knowledge involves stakeholders from diverse knowledge systems, boundary objects are necessary as a means of creating permeable knowledge frontiers that respond to the need for diffusing tensions associated with conflicting stakeholder interests. Boundary objects can be in form of maps, artifacts, infographics and other 
tangible tools, which provide a consistent platform for soliciting, clarifying and aggregating differing stakeholder viewpoints about priority challenges and possible solutions. However, it is important to use boundary objects of mutual interest, which maintains coherence across all sets of knowledge to promote cross-sectoral cooperation. (Nel et al. 2016; Safford et al. 2017; Vukomanovic et al. 2019). However, power dynamics are often a stark issue, since roles get re-defined and institutional arrangements are shifted, with the possibility of thwarting the processes of aggregating multiple sources of knowledge in leapfrogging cities towards sustainability (Wyborn et al. 2019; Turnhout et al. 2020). Although power is a contested conceptual lens, fused with meanings that transcend sustainability sciences to public administration and psychology, Fritz and Binder (2020) contend that power can be categorized as instrumental, structural, and discursive, and that these typologies manifest throughout the processes of actor selection and (re-)positioning, joint problem-definition, and the search for sustainability solutions. Scientists exercise instrumental power over co-production processes, whereas policy-makers as well as the funding bodies mainly wield structural and discursive power. The instrumental power of scientists often comes with the use of guidelines and toolkits on co-producing knowledge, which are for example used in stakeholder training workshops that usually redirect power into the hands of expert researchers, who reintroduce unfamiliar concepts and specialized terminology that can make local communities, funding agencies and policy-makers recede to the background (Kemp and Nurius 2015; DeLorme et al. 2016; Lotz-Sisitka et al. 2016; Gillis et al. 2017; Valley et al. 2018). Structural power comprises of multinational relationships, materials and ideas that for example frame research calls by funding agencies, which indirectly or directly influences the options that scientists take on to engage in projects on co-producing knowledge (Samoff 2003; Partzsch and Fuchs 2012; Akl and Khamis 2019).

Although scientists usually take on the role of selecting policy-makers and maintaining relationships with them, this is seldom a unilateral decision. Policy-makers too influence co-production processes by overtly or covertly demonstrating their interest in participating or, openly expressing skepticism about what the project intends to achieve. Therefore policy-makers can exert discursive power over problem-definition, actor selection and pathways for scaling up local solutions. However, the conception of power should not overlook contexts where scientists, funding agencies and policymakers are invited by local communities, to seize the learning and scale-up potential of local innovations. In this arena, power over locally-embedded knowledge often positions the local elite as the voice for the non-elite, thereby concealing the realities of individuals that belong to lower social strata in terms of education level, gender, economic class and caste (Buyana et al. 2020; Volken et al. 2018; Meylan et al. 2018; Castán Broto and Neves Alves 2018). It is often a blind spot for scientists, funding agencies and policy-makers, to critically inspect and interrogate the subjectivities brought on board by disparities in socio-economic status and identities amongst local communities, and by the different and sometimes conflicting mandates of government sectors, along which statutory power is exercised. This means that the promise of symbiotic relationships in co-producing knowledge may not come to fruition, if no explicit effort is made to interrupt the reproduction of unequal power relations. This paper draws on case study projects in African cities, to discern how expert power by academics, statutory power for policy-makers, and the power over locally-embedded 
knowledge by city residents are navigated when co-producing locally grounded knowledge and solutions for urban sustainability.

\section{Materials and methods}

\section{Study areas}

The case study projects were purposively selected from Durban and Stellenbosch in South Africa, as well as, Kampala city in Uganda (Fig. 1). Within each city, one human

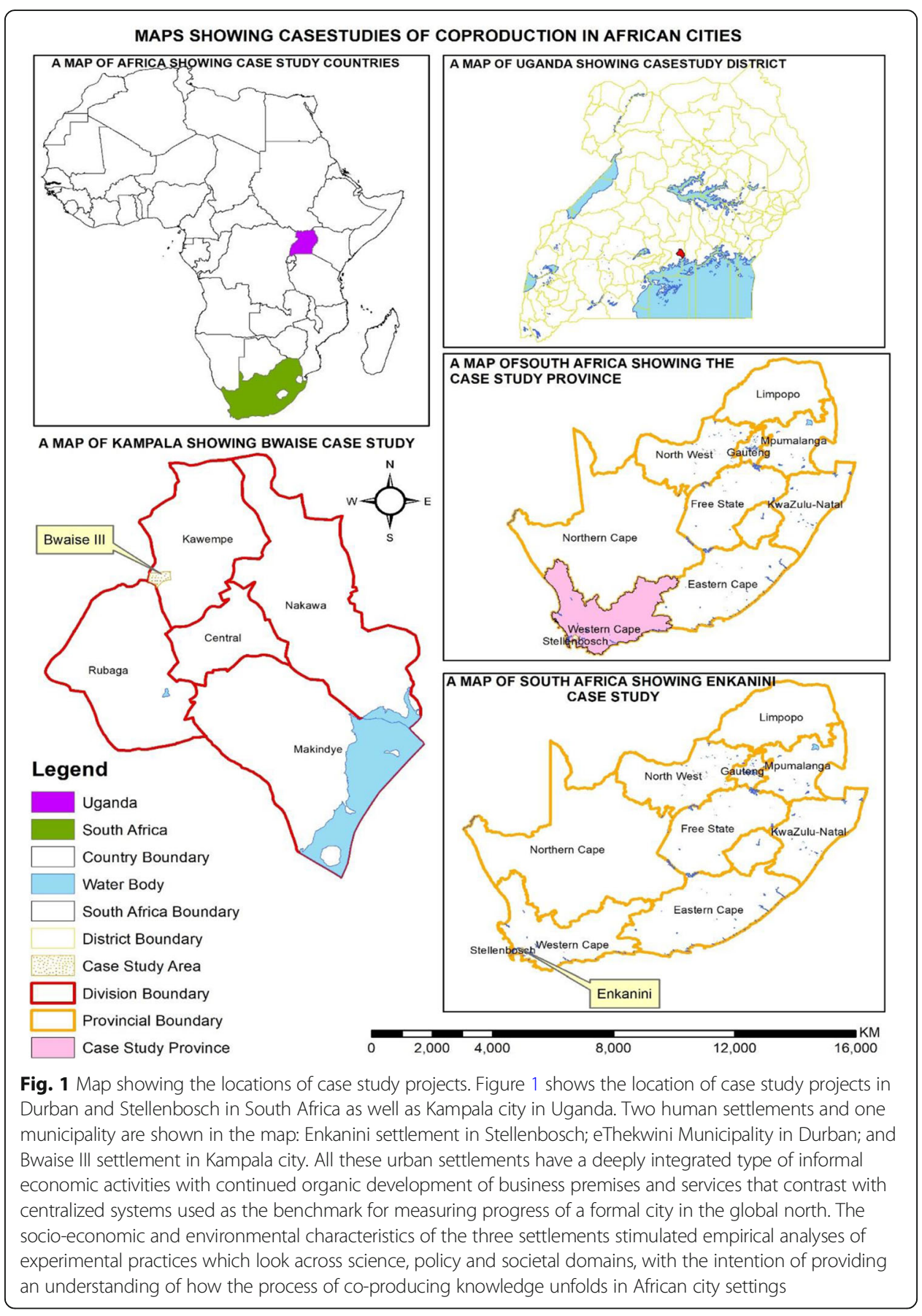


settlement was studied: Enkanini in Stellenbosch; eThekwini Municipality in Durban; and Bwaise III parish in Kampala city. Established in 2006, Enkanini is located approximately $4 \mathrm{~km}$ from the center of Stellenbosch town with over 6000 residents. About 2494 households live in shacks with no formal housing and drainage systems coupled with difficulty for the municipality to justify the provision of basic sanitation and energy services, as they do not receive rate payments from residents to cover these costs (Stellenbosch Municipality 2012). The settlement was created when the evicted backyard shack dwellers of the neighboring Kayamandi Township occupied the adjacent land. eThekwini Municipality, on the other hand, has more than 400,000 people living in informal settlements and located within KwaZulu-Natal (KZN). KZN is a sub-tropical coastal zone that stretches $580 \mathrm{~km}$, with disproportionately large human settlement and an average $2 \mathrm{~m}$ diurnal tidal cycle that makes the coast vulnerable to erosion (Fig. 1). Development in eThekwini increases bio-physical changes, leading to an escalation in environmental risks affecting coastal populations, infrastructure and natural coastal environments (eThekwini Municipality 2012).

Bwaise III is a commercial and residential township, located in the north-western part of Kampala city in Kawempe Division. The ecosystem of Bwaise III is under threat from population growth, but also erratic development, where plots of differing sizes are opened up for construction of housing, infrastructure, or industrial development, without attention to conservation of green areas. Development would contribute to greater energy efficiency but fuel switching from inefficient traditional fuels to efficient modern fuels and devices, within residential and commercial properties, is yet to take shape in Bwaise III (Okello et al. 2013). Charcoal is the preferred cooking energy, and adaptation strategies for energy scarcity have been devised at neighborhood scale. These strategies include self-generation (use of generators and solar panels), improved energy technologies (energy-saving bulbs and cooking stoves), adjustments in energy-use practices (abandoning boiling of water and foregoing hot water baths), adjustments in sleeping schedules, forsaking foods that require long hours of preparation alongside illegal theft and tapping of electricity (Mukwaya 2016). The socio-economic and environmental characteristics of the three case study areas stimulated experimental practices, which look across science, policy and societal domains for sustainable urbanization in an African context.

\section{Data collection and analysis}

A qualitative approach was used to collect data on the three case studies. Document review was guided by an overarching question that gave structure to the process of triangulating the findings with academic literature on cities. The question is: what coproduction processes were used in each case study, and how did power dynamics affect the process of attaining the jointly stated objectives? The review process was iterative and therefore no search terms or step-by-step methods of identifying material were used. Rather information was searched and extracted in a scoping way from each of the documents and websites (Teare and Taks 2020). Since the evidence was largely qualitative, a narrative synthesis was considered most appropriate coupled to the fact that the review question is a qualitative and interdisciplinary line of inquiry (Snilstveit et al. 2012). Project site visits enabled us to get involved in co-production processes and 
conduct interviews amongst community co-researchers, academics and policy bureaucrats. In the case of Kampala and Durban, our involvement was at the stage of jointly defining the research agenda, through joint learning workshops, held in July 2016 and December 2015 respectively. In both cases, the priority challenge(s) were framed cooperatively into research questions that included scientific, policy and societal aspects. Stakeholders also used the workshops to agree on the mechanisms that will be implemented throughout the research process to support the generation, integration and sharing of knowledge. In Stellenbosch, our participation was through site visits to locations where the iShacks had been installed, with guidance from postgraduate students who had been involved right from the start of the projects.

Like the other two cities, the selection of interviewees in Stellenbosch was done purposively to reliably permit engagement with actors who had come across one or all the levels of navigating power dynamics in co-production processes (Table 1). We discerned the navigation of power dynamics in co-production processes at two levels. The first level is science for policy and city residents, and the second level is science with policy and city residents. Science for policy and city residents is conventional in nature, where scientists are the producers of knowledge whereas policy-makers and city residents are the targeted end-users of knowledge. In this situation, scientists conduct research and take the results to policy-makers and city residents for discussion and adoption after completing the research process. Science with policy and city residents on the other hand, is where scientists, policy-makers and city residents have an equal chance to be producers of knowledge. The position of policy-makers and city residents changes, from end-users to co-bearers of knowledge with scientists. Although the two levels of co-producing knowledge provide an environment for engagements amongst scientists, city residents and policymakers, science with policy and city resident is what was followed during the process of conducting interviews, because it offers a better understanding of the organizational arrangements that influence power dynamics along three parameters, that is: i) co-framing research agendas; ii) co-designing methodologies for generating and use of knowledge; and iii) co-experimentation of scalable local innovations.

Thirty (30) respondents were interviewed in total, 12 in Kampala, 8 in Durban and 10 in Stellenbosch. Besides the ones in Kampala and Durban, who were interviewed on the sidelines of stakeholder workshops, many of the respondents in Stellenbosch had to be contacted from homes in Enkanini (especially the community co-researchers) or at the work place in the case of policy-makers and scientists. Analysis of interview data was conducted as conversations were being carried out. This allowed immediate grouping of responses to ultimately triangulate responses with the data obtained from documents, and in line with the review question. The project site visits and interviews added in-depth knowledge on how the actors involved confronted institutional mandates that define the rules and regulations for collaboration. The interviews were also key in understanding how each actor navigated power dynamics in co-production and legitimized their knowledge on sustainability challenges at a local scale. The openended questioning revealed that formal workshops and informal discussions at health breaks influenced the re-definition of actors' roles and stabilized the social boundaries. During the stakeholder workshops in Kampala and Durban, both academics and nonacademics intuitively took on different roles. These included: coordinators, penholders, intermediaries and facilitators of joint learning and planning. 
Table 1 Levels of navigating power dynamics in knowledge co-production processes

\begin{tabular}{|c|c|c|}
\hline Levels & $\begin{array}{l}\text { Forms of } \\
\text { interaction }\end{array}$ & Purpose of interaction \\
\hline \multirow[t]{2}{*}{$\begin{array}{l}\text { Level 1: } \\
\text { Science for } \\
\text { policy and } \\
\text { local } \\
\text { communities }\end{array}$} & $\begin{array}{l}\text { Single one-way } \\
\text { interaction }\end{array}$ & $\begin{array}{l}\text { "informing": relevant } \\
\text { information from study } \\
\text { results are } \\
\text { communicated from } \\
\text { one side to the other } \\
\text { (science to city residents } \\
\text { and / or science to } \\
\text { policy) }\end{array}$ \\
\hline & $\begin{array}{l}\text { Multiple one-way } \\
\text { interactions }\end{array}$ & $\begin{array}{l}\text { "Informing across sectors } \\
\text { and scales": Scientists } \\
\text { exchange relevant } \\
\text { information from studies } \\
\text { with policy-makers and } \\
\text { city residents at munici- } \\
\text { pal, national, regional } \\
\text { and global scale, and } \\
\text { the policy-makers and } \\
\text { city residents are drawn } \\
\text { from different sectors } \\
\text { such as health, transport, } \\
\text { housing and energy. }\end{array}$ \\
\hline
\end{tabular}

Level 2: Collaborative Science with Research policy and local communities
"Co-framing research agendas and Codesigning methodologies": scientists from different disciplines work with city residents and policy-makers across sectors and scales, to define the research problem and methodology, and go ahead to work hand in hand to generate and disseminate the results.

Joint decision making and implementation of projects using boundary objects

"Co-experimentation and joint action for change": scientists from different disciplines not only undertake research with city residents and policymakers across sectors and scales, but also jointly create, test or take to scale solutions with the aim of bringing about transformative change in society.

\section{Scientists are the \\ producers and \\ disseminators of \\ knowledge \\ Policy-makers and city \\ residents are the \\ targeted end-users of knowledge}

Scientists, policy-makers and city residents are co-producers, codisseminators and coend users of knowledge
Guiding questions for discerning power dynamics

\section{What platforms,}

content, messaging, and

language have you

used to make the

findings from this project accessible by non-academic actors (municipal officials, national government agencies, international partners/donors)?

Did the activities and discussions around the project involve inviting municipal officials, central government agencies and city residents to take part? If not, why? If yes, how?
Were there groups of people (academic and non-academic) who influenced the process more than others? Why do you think this happened?

- Were there groups of people who took part but had very little influence? Why do you think this happened?

- Based on the objectives of the project, were any groups of people left out from the coproduction process who should have been there? Why do you think this happened? - Were all perspectives, ideas and knowledge offerings integrated equally into the coproduction process? - Do you think there were any rules (formal or informal) that supported one group being heard over another?

- Is there anything else related to how groups of people participated in the co-production process that you think is important to discuss? 
The intermediary role involved acknowledging each actor's role through functional participation, whereas the facilitation required the academics to continuously promote openness and deliberation among the actors. Pen-holding pertains to documenting the outcomes of jointly defining a research agenda, as the community co-researchers coordinated the process of making the different perceptions of local communities visible and linking them to the co-production process. Co-production across the case studies indicates a departure from highly institutionalized transdisciplinary partnerships in seeking to understand real-world sustainability challenges. The institutionalized modes of co-production are usually initiated by (1) a shared framework to support more systematic knowledge development and use, (2) identification of barriers that create a gap between stated urban goals and actual practice, and (3) identification of strategic focal areas to address this gap (Scholz et al. 2009; Seidl et al. 2013; Future Earth 2016; Beier et al. 2017; Montana, 2019). With limited formal leadership to engage with, partnerships across the case studies were mainly with informal social actors from local communities. Through an iterative mode, the roles of each actor from science, policy and societal domains were defined and re-defined, without basing on pre-determined guidelines and the sustainability challenges upon which co-production processes were predicated are in informal urban settlements.

\section{The case study projects}

\section{Briquettes from organic waste in Kampala city, Uganda}

Organic waste in Kampala city, including both human and solid waste, is largely managed through practices that are environmentally unfriendly, which degrade aesthetics with adverse health and environmental outcomes. However, organic waste is resourceful if utilized for nutrients recovery or turned into energy briquettes that can provide alternative livelihood strategies with a high potential for integrating the urban poor into the urban economy. Solid waste management interacts with climate system through generation of methane, which is highly potent that cumulatively contribute to Greenhouse Gases emissions. Kampala Capital City Authority (KCCA) is grappling with managing wastes and the model which has been pursued for long is the collect, transport, dispose wastes at a landfill with several challenges including accumulation of leachates, contestations from the community close to the landfill and waste picking that is often seen as scavenging. Knowledge exists on generation, management practices, and environmental problems, costs incurred by KCCA and costs to communities and the largely engineering solutions. But the knowledge about the transformation of organic wastes into usable products has remained at micro scale in communities where research and pilots have been undertaken in the last two decades. The alternative means of managing the organic waste by turning it into resourceful products such as energy briquettes is estimated to recover less than $5 \%$ of the organic wastes generated in the city if transformation of bio-waste is done at or near the source of the bio-waste, to reduce volume and bulk, and optimize transportation costs (Table 2).

Building on existing knowledge, a research project known as Localising Norms on Sustainable Energy in Kampala (LoNSEK), was designed to enable demonstrable strategies for transformation of waste management in the city, while using energy briquettes as the boundary object for engaging a selected number of local community groups 
Table 2 weighting of waste to fuel conversions in Kampala city

\begin{tabular}{llll}
\hline $\begin{array}{l}\text { Bio-waste } \\
\text { stream }\end{array}$ & $\begin{array}{l}\text { Weight loss during briquette- } \\
\text { making }\end{array}$ & $\begin{array}{l}\text { Time for boiling 10 I of water } \\
\text { (minutes) }\end{array}$ & $\begin{array}{l}\text { Burning duration } \\
\text { (minutes) }\end{array}$ \\
\hline Maize cobs & $75 \%$ & 25 & 300 \\
$\begin{array}{l}\text { Banana } \\
\text { peelings }\end{array}$ & $83 \%$ & 20 & 330 \\
$\begin{array}{l}\text { Potato peelings } \\
\text { Food waste }\end{array}$ & $77 \%$ & 30 & 270 \\
(maize) & & 25 & 250 \\
$\begin{array}{l}\text { Mushroom } \\
\text { waste }\end{array}$ & $50 \%$ & 35 & 180 \\
Cow dung & $65 \%$ & & \\
Saw dust & $36 \%$ & 25 & 250 \\
Charcoal dust & $0 \%$ & 35 & 210 \\
\hline
\end{tabular}

Source: authors' review of a research project on augmenting waste economies in Kampala city, January 2018

(Table 3). From the local community groups, a research team of six community coresearchers was selected from Bwaise III parish, to work with three policy actors from Kampala Capital City Authority (KCCA), and four academic researchers from Makerere University Uganda and University of Nairobi. Through a joint learning workshop, the academics initiated the mentioning of research questions as: i) which strategies would deliver on sustainable energy in Kampala city? ii) How would such strategies be implemented and connected to initiatives on sustainable energy in your neigbourhood? Feedback from the groups was that the questions could not attract deeper engagement with societal viewpoints, but elicit generalist perspectives that are not characteristic of local contextual dynamics. The contestation was that local community actors, even with guidance from the academics, could not easily relate the questions to their general sense of precariousness, with regard to work, energy, water, health and housing in the city. Notwithstanding the sentiments that the future might not be any better than the present, community co-researchers were facilitated with neon sticky notes and flip charts to give narratives on what it means to live and work sustainably in the city and its connection to sustainable energy. But in order to develop a research agenda on that is scientifically-relevant and socially-valuable, the energy briquettes (Fig. 2) were used to permit social learning and engagement pertaining to sustainability in the city.

Table 3 Local Community Groups

\begin{tabular}{|c|c|c|c|}
\hline Organization & Activities & Products & Neigbourhood \\
\hline LUCHACOSS & $\begin{array}{l}\text { Collection of plastics and banana peelings } \\
\text { for sale, making of briquettes, paper-bags }\end{array}$ & $\begin{array}{l}\text { Charcoal, briquettes, } \\
\text { animal feeds }\end{array}$ & Kasubi \\
\hline KISENSU & $\begin{array}{l}\text { Brick making, drawing sand from Kiwunya } \\
\text { drainage channel }\end{array}$ & Bricks, sand & Bwaise \\
\hline KALOCODE & Making charcoal, briquettes, crafts & $\begin{array}{l}\text { Charcoal, briquettes, } \\
\text { crafts }\end{array}$ & Kasubi \\
\hline KACODA & Making charcoal, briquettes, compost & $\begin{array}{l}\text { charcoal, briquettes, } \\
\text { compost }\end{array}$ & Lubya \\
\hline MYC & Poultry, urban agriculture and forestry & $\begin{array}{l}\text { Chicken litter, nursery } \\
\text { beds for trees and flowers }\end{array}$ & Lubya \\
\hline $\begin{array}{l}\text { Kasubi Market } \\
\text { Vendors Association }\end{array}$ & $\begin{array}{l}\text { Urban greening through tree planting, } \\
\text { promoting use of solar energy, selling used } \\
\text { spare parts for cars and motorcycles }\end{array}$ & Solar systems & Kasubi Market \\
\hline
\end{tabular}




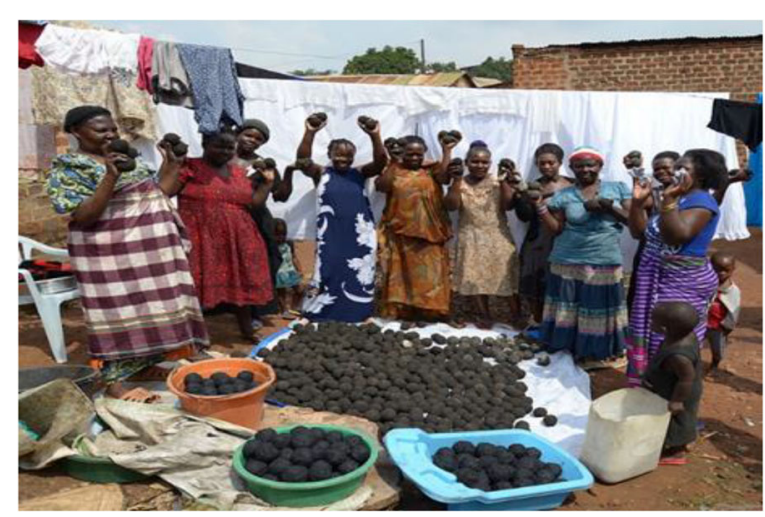

Fig. 2 Energy briquettes as the boundary object for social engagement and learning. Figure 2 represents the power over locally-embedded knowledge, which was leveraged by academics and policy-makers in Kampala city, using energy briquettes as the boundary object, to demonstrate that is possible to resolve sustainability challenges such as urban poverty, inequality and climate change. The LoNSEK project has worked with Kampala Capital City Authority (KCCA) on how to take lessons from alternative organic waste management to initiate institutional support for scaling up at city-regional scale that would reduce costs of waste transportation to the landfill center. According to policy-makers from KCCA, the city authority spends an estimated 1/3 of its annual budget to managing wastes, $3 / 4$ of which are organic and if turned into energy, KCCA would save, communities would gain businesses and users would have a reduced per capita emissions which at the moment stands at $\sim 200 \mathrm{~g}$ per person per year. In order to disseminate knowledge on piloted and innovative ideas on turning waste into energy briquettes, the LoNSEK project organized community barazas in Bwaise III parish. More community groups became interested to join the business of making energy briquettes as an alternative cooking energy, which is sustained by the large volumes of organic material flowing into the city. At the end of the project, there were over 10 energy-briquette making enterprises across Bwaise III, which joined an umbrella enterprise known as Lubaga Charcoal Briquette Cooperative Society Limited (LUCHACOS)

Scientists used energy briquettes as the binding symbol of reference to solicit policy and local resident's views, and to have a discursive approach to re-analyzing the advantages and disadvantages of existing waste management practices, with a substantial representation of local female residents as shown in Fig. 2. Energy products that are burnt without generating smoke topped the local community actors' perspectives on sustainable energy, while the price of alternative energy products was significantly associated with household expenditure in the city. Closer proximity to the central business district, roads, workplaces, cheaper food, and electricity services were among the concerns raised by the local community actors in relation to accessing affordable energy. Of particular interest was adaptation strategies for energy scarcity including self-generation (use of generators and solar panels), improved energy technologies (energy-saving bulbs and cooking stoves), adjustments in energy-use practices (abandoning boiling of water and foregoing hot water baths), adjustments in sleeping schedules, forsaking foods that require long hours of preparation alongside illegal theft and tapping of public electricity. Briquette-making was connected to adaptation to climatic hazards, especially flooding and the resultant disease outbreaks like cholera and malaria. The connection is that briquette-making requires large volumes of wastes, which is usually picked from illegal waste dumps in the neigbourhood and drainage channels. This leads to draining stagnant water, cleaning drainages regularly, filling with soil to raise ground levels, digging trenches around the houses, desilting drainage channels, raising embankments along the drainage channels, raising latrine sludge chambers, suspending houses on stilts among others. Based on these local community perspectives, the research questions changed to: i) how to enable transition of the current micro-scale interventions of 
energy briquettes to meso and macro-scale within the context of Kampala city-region; and ii) how to enable development of products and a business model that can have double edged outcomes of mainstreaming the urban poor into the urban economy while reducing the adverse health effects of indiscriminate dumping and management of wastes in the city. These questions became the joint research agenda for the academic, community representatives and municipal officials from Kawempe Division of KCCA.

With support from community representatives, academic researchers established informal relationships with the associations at local scale. It is through such relationships that the LONSEK project acquired both an emic and etic understanding and experience of what it means to access energy sustainably in Bwaise III parish. By becoming embedded-researchers that participate in initiatives undertaken by low-income groups to extract and add value to materials from the waste stream, through the use of organic waste for nutrient recovery and production of energy briquettes, the neighborhood associations were able to narrate their own life course, as the act of telling a story that is strongly linked with the process of immersion into experimentation of waste recycling for production of energy briquettes. Local community groups talked about their energy biographies, going back to their earliest memories, and through these narratives it was possible to recreate the actions of waste vendors and green charcoal producers. However, the aim was precisely to reconstruct their lived experience, invested with meaning as it is, and, therefore, to learn about the shifts in the roles of actors and approaches to experimentation of sustainable energy transitions in an informal settlement.

Dialogues with the local community representatives revealed that energy-briquette making seeks to balance the need for energy and urban environmental health protection through organic and inorganic waste re-use and recycling. This involves recovering re-usable and recyclable items from the waste stream including: polythene bags for growing mushrooms; banana-cassava-sweet potato peelings and cow dung for compost; plastic bottles for packing juice and drinking water. Other wastes include: newspapers for making tray eggs; tins and mineral water bottles for making shoe soles; bottle straws for knitting baskets; charcoal and saw dust for reducing odor from latrines; oily milk packages used as fuel for cooking; discarded cardboard serving as walls and roofs of houses for a cool indoor climate. The most common waste innovation marketed by all these types of groups are energy briquettes. These are created when banana peels and other dried organic material is put into a large bin and then burned at high heat and low oxygen which creates a kind of charcoal material but made out of garbage instead of trees. This is then crushed and mixed with clay and cassava flour (as a glue) and rolled into balls to create briquettes that can be used instead of charcoal. One community co-researcher from Kasubi Community Development Association (KACODA) reported that $10 \mathrm{kgs}$ of saw dust are mixed with 4 bottles of mushroom seeds together with 201 of water and rice husks, stirred, cooked and then left to decompose for 6 months so as to have fertilizers. The resultant volume of fertilizers can enable the farmer establish 60 mushroom gardens of $4 * 4$ square meters that can fetch a daily income of USD 15. It was noted that this innovation is a technological transfer from India and other parts of the world, where the some processes have been widely applied to biomass in order to take advantage of its energy potential (Yaman et al. 2000; Stolarski et al. 2013). 
Another experiment is the generation of bio-gas from organic waste. This experiment is relevant for Kampala city because KCCA spends an estimated 1/3 of its annual budget to managing wastes, $3 / 4$ of which are organic and if turned into energy, KCCA would save, communities would gain businesses and users would have a reduced per capita emissions which at the moment stands at $\sim 200 \mathrm{~g}$ per person per year (Kampala Capital City Authority, KCCA 2018). The local community actors acknowledged that if the generation of bio-gas kicks off substantially, energy will be generated from solid waste will be generated. The official argued that this can enable Kampala city generate what is required for daily consumption and the remainder is sold to neighboring districts for revenue generation. But knowledge about the transformation of organic wastes into health-friendly energy products has remained at micro scale in communities, even where research and pilots have been undertaken. And yet the transition of micro-scale interventions of energy briquettes to meso and macroscale, would not only integrate the urban poor into the urban economy but also reduce the adverse health effects of indiscriminate dumping and management of wastes from energy-related activities. The scalable nature of energy-briquette making and bio-gas amongst unregulated networks of neighborhood groups, not only permitted the discernment of different forms of knowledge, but also offered insights on the co-benefits to health and poverty-oriented energy transitions at neigbourhood scale.

\section{A locally-appropriate costal vulnerability index for visioning sustainable climate action in Durban}

After learning that encounters with beach erosion, coastal flooding, and other climatic impacts cannot be solved based on expert science alone, the city of Durban decided to build on the voices of actors at multiple scales in drafting a coastal vulnerability assessment. Memories of extreme storm events in March 2007, unearthed by presentation of images from the archives of the Durban Environmental Planning and Climate Protection Department (2012), enabled local residents to construct narratives that shaped the process of jointly developing local vulnerability assessment tools, as opposed to simply utilizing pre-formulated tools, which often render assessments expert-led and will neglect community-based knowledge. Local residents and municipal officials utilized mobile phones and digital cameras to take images of affected landscapes, buildings and communities. With facilitation by the experts, local actors distilled their experiences and developed a set of environmental, social, and economic indicators for co-designing a localized vulnerability assessment. According to the Durban Environmental Planning and Climate Protection Department (2012), coastal geographers and consultants had initially designed tools depicting three sea-level rise scenarios: $300 \mathrm{~mm}$ (12 in.), $600 \mathrm{~mm}$ (24 in.) and $1000 \mathrm{~mm}$ (40 in.). By positioning local residents as co-designers of the vulnerability index, social, economic, built-environment, and physical characteristics were integrated into a single tool. The images taken and pictures drawn by the local residents were then placed on the right of each indicator. The socio-economic dimensions of the coastal vulnerability index (Table 4) made it a boundary object for enabling residents to easily visualize, interpret and associate their own experiences with expert and policy knowledge. 
Table 4 Socio-economic dimensions of the coastal vulnerability assessment tool

\begin{tabular}{|c|c|c|}
\hline Type of risk & Socio-economic dimensions & Indictor for vulnerability assessment \\
\hline Loss of property & $\begin{array}{l}\text { - Loss of beach holdings } \\
\text { - Tenure insecurity due to undocumented } \\
\text { property rights } \\
\text { - Deterioration in housing standards }\end{array}$ & $\begin{array}{l}\text { - Beach-based businesses operated by plot } \\
\text { - Number of affected persons with document } \\
\text { and undocumented property rights by race } \\
\text { and gender } \\
\text { - Proportion of affected persons updated } \\
\text { on municipal beach management laws by } \\
\text { race gender (e.g. the Integrated Coastal } \\
\text { Management Act). }\end{array}$ \\
\hline Joblessness & $\begin{array}{l}\text { - Loss of merchandize by SME's (food stalls, } \\
\text { artisanal units) } \\
\text { - Reduced income from natural resources } \\
\text { (sand, quarries, fish) } \\
\text { - Conflict in and with SME associations } \\
\text { - Decline in production of staple crops } \\
\text { (e.g. maize) as a result of climate change }\end{array}$ & $\begin{array}{l}\text { - Number of affected SMEs by gender and } \\
\text { race of proprietor } \\
\text { - Number of affected livelihoods depending } \\
\text { on natural resources } \\
\text { - Number of SME associations involved } \\
\text { - Shifts in planting seasons } \\
\text { - Decline in crop harvest }\end{array}$ \\
\hline $\begin{array}{l}\text { Social } \\
\text { disengagements }\end{array}$ & $\begin{array}{l}\text { - Loss of access to public services } \\
\text { - Loss of access to common property } \\
\text { services (fishing grounds, cemetery, } \\
\text { quarries) } \\
\text { - Dismantling of kinship, local voluntary } \\
\text { associations, marriages, cultural clashes } \\
\text { with host population }\end{array}$ & $\begin{array}{l}\text { - Affected voluntary associations by } \\
\text { settlement } \\
\text { - Affected health units by settlement } \\
\text { - Common property services by village }\end{array}$ \\
\hline $\begin{array}{l}\text { Morbidity and } \\
\text { Mortality }\end{array}$ & $\begin{array}{l}\text { - Outbreak of vector-borne diseases/HIV/IDS } \\
\text { - Wife/husband buttering } \\
\text { - improvised sewage systems increase } \\
\text { vulnerability to epidemics and chronic } \\
\text { diarrhoea, dysentery }\end{array}$ & $\begin{array}{l}\text { - Number of illnesses reported } \\
\text { - Number of gender-based violence } \\
\text { incidences reported }\end{array}$ \\
\hline
\end{tabular}

Source: eThekwini Municipality, 2016; and authors' aggregations of document and interview data, 2017

The content of the tool became cross-disciplinary in nature, with social, economic, geographical and environmental indicators that required both conventional expertise such as oceanography, and more recent disciplines like coastal sociology. However, there were limitations associated with a community-led process in co-framing the vulnerability assessment tool. The local elite were the voice for the non-elite, thereby concealing the realities of certain under-educated individuals, and experts did not critically inspect the process in order to allow the non-elite voice their experiences. But the lead scientists made an effort to have one-on-one interviews with the local actors whose voices had not been heard during the group work. To refine the vulnerability index, support was sought from Corporate Geographic Information System, used by the KwaZulu-Natal Provincial authorities and eThekwini Municipality. This enabled collation of societal and policy views within the vulnerability assessment tool, thus providing an apt context for co-expanding the social role of community-led design and innovation, given that purely technocratic approaches had failed to resonate with the lived experiences of costal dwellers in Durban.

Designers and geographers were enabled to become facilitators of a process in which participants visualized social, environmental and technical arrangements for confronting coastal erosion, and how these can be tested and improved collaboratively over time. Open-ended engagements gave room for flexibility so that changes can be absorbed in real time and continual learning is ensured. The community agents took on the role of provocateurs, who critically examined the societal relevance of the vulnerability assessment tool. By acquiring such a hybrid role, community agents were able to focus greater attention on social and cultural problems such as homelessness, insecurity, poor health, loss of property, social disarticulation and sanitation that are 
associated with coastal flooding and beach erosion. Although the initial tool had gone through a number of iterations to ensure that it is user-friendly to the municipality official and capable of generating scientifically accurate and credible information, it was largely focusing on storing climate change documentation produced by the Environmental Planning and Climate Protection Department and integration of the Geographic Information System tool, which spatially represents the climate change impacts projected for the eThekwini Municipal Area (projected mean annual temperature increase, and mean annual rainfall increase).

The integration of socio-economic, climatic and sea-level rise indicators facilitated the review of the Community Adaptation Plan Project that had been initiated in 2010. The solutions co-created included field trials for shifting planting dates and ensuring that crops are irrigated, as pathways for adapting to climate change conditions. Community members were also asked to taste food cooked using the alternative staple crops, like amadumbes, cassava, pumpkin and sorghum, in order to test the palatability and acceptability of these alternative crops. The field trial undertaken at Luganda School focused on controlling surface run-off that was eroding the school grounds and causing flooding. The selected interventions increased water storage on the school grounds with water being harvested off school-building roofs. This water is utilized by community members for their gardens as well as for a school vegetable garden which was established to provide vegetables to the school children. The banks of the school have also been stabilized with indigenous vegetation and vetiver grass to minimize flooding after heavy rainfall. This demonstrates how community-level climate protection planning and common sense can improve the lives of community members in a tangible way. These locally-embedded solutions speak to how substantial investments in co-produced adaptation science can facilitate substantial rates of implementation of adaptation actions. Therefore coastal erosion in Durban was the boundary subject for drawing in and bridging knowledge forms across expert scientists, local community actors and municipal offices, but without necessarily basing on past experiences from elsewhere thus depicting an anticipatory-practice for leapfrogging ocean health and sustainability.

\section{An improved shack dwelling for slum upgrading in Stellenbosch, South Africa}

In 2011, as part of their postgraduate studies, a group of students from Stellenbosch University in South Africa agreed to research Enkanini, one of South Africa's urban informal settlements with a population of 6000. The students' mutual research question was this: what does in situ upgrading (as specified by government program) mean in practice from the perspective of the average shack dweller living in Enkanini? With support from their academic supervisors, the students applied a transdisciplinary research approach as the avenue for changing the rules of engagement with societal actors, by way of establishing informal relationships with community actors in a settlement that is mostly devoid of formal structures. It is through such relationships that the study acquired both an emic and etic understanding and experience of what it means to live in a shack. By becoming activist-researchers and leading slum improvement campaigns, the students built relationships with residents across different demographics and peer networks, mainly the Informal Settlement Network, a social 
movement that worked with Stellenbosch Municipality officials who also had formal and informal contacts with the network.

The students' understanding of upgrading slums included municipal delivery of electricity for streetlights, water, sanitation, roads, storm water, and solid waste services. But this could only be possible if Enkanini met two formal standards by the municipal government: i) it was recognized legally as a permanent settlement, and ii) the land on which it was located was zoned residential. As Enkanini met neither of these legal standards, a court issued an order for its removal, but with this was not enforced by the local authorities Even if the standards were met in Enkanini, upgrading meant waiting for waste-collection systems, electricity, and water grids to be put in place by the government. According to the Western Cape Provincial Government, this process could take about 8 years following legalization and rezoning. The research question changed to: what could be done before the arrival of the municipal services to improve quality of life? This reframing sparked the student's collective imaginations on alternative infrastructure solutions that could transform Enkanini. The postgraduates, who now had to combine university research expertise with the practical knowledge on Enkanini and the community groups, had to form partnerships with ingenuity and capacity to make a difference. The students, working together in groups of two to three, came up with presentations for senior researchers within the university and municipal officials outside the university, who were supportive but suspicious about their endeavors, due to the project-based learnings and micro-level innovations have not helped improve upgrading performance (Gulyani and Bassett 2007; Jones 2012). The students focused their presentations on research questions that treat scientific and societal knowledge with equal value in order find solutions to informal settlements.

One of the students framed her research questions as follows:

1. How are social and technological considerations configured in the production of sanitation interventions in informal contexts?

2. What are the challenges of co-producing knowledge in an informal settlement context?

3. How can design facilitation enhance participation in contexts such as informal settlements that have traditionally been under-served by professional design?

While drawing on research by Ziblim et al. (2013) and Muzondi (2014) on residents that are susceptible to poor living conditions in South Africa, the student, who is an industrial designer, argued that co-producing sanitation enables residents of informal settlements to situate their experiences within the academic research agenda, and taps into the spirited behavior of underprivileged citizens to lead intra-community and collaborative problem solving. Her presentation and that of colleagues, were refined into a transdisciplinary research enterprise that challenged the university to break out and use its resources, to build the capacity of other researchers to undertake collaborative studies that can incrementally bring about an improved shack instead of low-cost high-rise apartments. After months of informal and formal interactions between the university, municipality and the community, the iShack was designed by industry actors $-\mathrm{a} 14.2$ $\mathrm{m}^{2}$ dwelling incorporating fire-retardant insulation, passive heating and cooling materials, orientation to maximize solar penetration, a solar panel, and a gutter to capture 
rain water. The iShack (Fig. 3) became the boundary object for social engagement between the researchers and the community.

Engagements with the iShack changed the character of researchers and community values in ways that formed the guiding principles and design of the iShack Project. The project is now providing solar electricity, on a pay-for-use basis, to residents of an informal settlement in Stellenbosch (Enkanini), South Africa. Over 1500 clients have been targeted and a group of local franchisees have been trained and labelled as "iShack Agents". The agents install and maintain the solar systems and to market the service in their community. The clients pay a monthly fee for the service to ensure long term operational sustainability. The energy service provides lighting, television, cell-phone charging and additional energy for music, DVD players and radios. The utility is scalable and in future, fridges and water heaters will be added. This case study demonstrates how the replicated-practice of knowledge integration requires societal partners that can support a more agile learning environment for university students while converging the usual split between societal activism and scientific research.

\section{Power dimensions and the use of boundary objects}

Stakeholders across the case studies represent three forms of power: expert power held by academics; the statutory power of policy-makers; and power over locally-embedded knowledge in the case of local residents. Power is often concentrated in the hands of scientists, especially at the beginning of projects. They take the lead in convening different stakeholders to work together on a specific urban sustainability challenge. Scientists are capable of introducing specialized terminology at the stage of joint definitions of research agendas, which makes local communities and policy-makers negotiate their way into exercising statutory power and power over locally-embedded knowledge respectively, with the purpose of re-designing the content of research questions. Policy-makers at the municipal and national level use statutory power to ensure that the coproduction process speaks to the existing framework of policies, laws and regulations

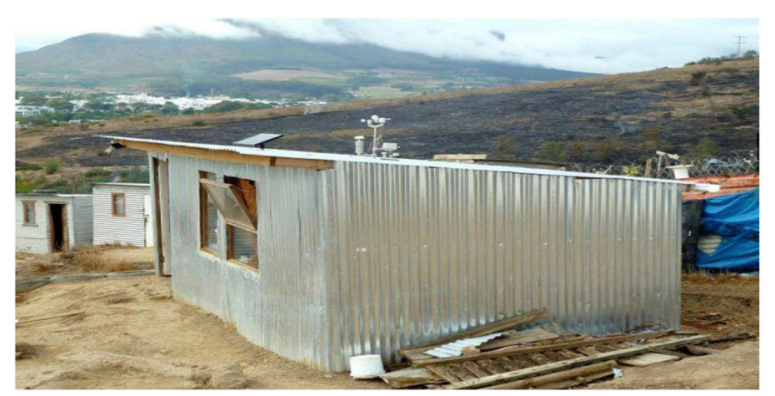

Fig. 3 The improved shack in Enkanini-Stellenbosch, South Africa. Figure 3 is a design of the improved shack (iShack) in Enkanini-Stellenbosch (South Africa) that became the boundary object for social engagement and learning among the researchers and community members, and later attracted the attention of industry and municipal authorities as an innovation that could address the need of underserved urbanites in informal settlements, as they await formal service delivery from government. The iShack Project was pioneered by the Sustainability Institute of Stellenbosch University, and it demonstrated how experimenting the design of interconnected infrastructures (housing, energy and sanitation infrastructures), can build bridges across academic, policy and local community actors sustainability in informal settlements. In broader terms, the iShack signifies that cities in Africa comprise of agile informal settlements, which harbor micro-scale innovations and local community actions that can open up unique pathways for leapfrogging sustainability 
in the city. This power can also be helpful in fostering collaboration between sectors with differing mandates. Power over locally-embedded knowledge is not based on institutional mandates and formal structures. Rather it stems from the actions and networks of neighbourhood groups, citizen coalitions, associations of informal urban service delivery operators, and federations of city traders. The use of micro-scale innovations to address pressing urban sustainability challenges, gives a platform where this form of power drives the exchange of knowledge, to critically reflect on local community positions and experiences, and for thinking about ways to interrupt the reproduction of unequal power relations using boundary objects.

Boundary objects as artifacts, symbols and networking platforms offer the basis for navigating the differentiated forms of power, to aggregate and legitimize multiple knowledge sources (Star and Griesemer 1989; Sapsed and Salter 2004). Boundary objects can also be the means through which the objectives of empowerment and societal transformation are directly or indirectly associated with co-producing knowledge in a given context (Brown and Duguid 2001; Oswick and Robertson 2009). The briquettes from organic waste as alternative cooking energy for households in Kampala; a locallyappropriate costal vulnerability index for visioning sustainable climate action in Durban; and an improved Shack dwelling for slum upgrading in Stellenbosch; feature as the mechanisms for jointly generating and piecing together scientific, policy and societal viewpoints on urban sustainability issues. As symbols that hold the potential to turn local sustainability challenges into opportunities, these boundary objects led to knowledge exchanges that disrupt actors' identities along socio-economic categories, thus reducing the possibilities of unequal power relations in co-producing knowledge. The boundary objects, as a common frame of reference for soliciting views from and amongst different actors, facilitated dialogue in a way that flattened hierarchies. For instance, the use of briquettes from organic waste as the boundary object for the project in Kampala helped to establish joint problem ownership, build mutual trust, and shift stakeholder discussions from individual interests and institutional roles to the desired change of cleaner and affordable household cooking energy. While co-producing knowledge was steered by academics, the briquettes were the means to engage local city residents, mainly women, in social learning what on could be done in collaboration with KCCA to localize norms on sustainable energy. City residents spoke of the briquette as a means of adjusting energy technology to their experience and their need for sanitation, waste management and employment. Since this, according to city resident's knowledge, is not possible with other energy sources such as cooking gas and electricity provided by government, the organic briquette provided the opportunity to redirect the power of knowledge generation into the hands of local communities.

As shown in Table 5, the circumstances that permit boundary objects to interrupt the reproduction of unequal power relations differ by urban context and objective of co-producing knowledge. In the case of Stellenbosch, power was interrupted as the coproduction unfolded using materials, such as solar lighting, that are already known to stakeholders across science and society as a solution that had worked in projects elsewhere. In Durban, power levelled through an anticipatory process of imagining pathways to sustainable climate action with policy and city resident actors that are directly affected by the challenge of climate change at a personal level. Instead of standing out as experts on costal vulnerability, scientists in the case of Durban receded to the 
Table 5 Forms of power in relation to boundary objects (authors' elaboration)

\begin{tabular}{|c|c|c|c|c|}
\hline $\begin{array}{l}\text { Dimensions } \\
\text { of Power }\end{array}$ & Actors & $\begin{array}{l}\text { Case study } \\
\text { location }\end{array}$ & Boundary object & $\begin{array}{l}\text { Processes of interrupting } \\
\text { unequal power relations }\end{array}$ \\
\hline $\begin{array}{l}\text { Expert } \\
\text { power }\end{array}$ & $\begin{array}{l}\text { Scientists/ } \\
\text { researchers }\end{array}$ & $\begin{array}{l}\text { Kampala- } \\
\text { Uganda }\end{array}$ & $\begin{array}{l}\text { Energy briquette from } \\
\text { organic waste }\end{array}$ & $\begin{array}{l}\text { - Energy briquette as the } \\
\text { symbol for turning } \\
\text { environmental health } \\
\text { burdens into livelihood } \\
\text { opportunities. } \\
\text { - Energy briquette enterprises } \\
\text { as the means to the policy- } \\
\text { shift away from landfill } \\
\text { solutions }\end{array}$ \\
\hline $\begin{array}{l}\text { Statutory } \\
\text { power }\end{array}$ & $\begin{array}{l}\text { Policy-makers/ } \\
\text { municipal } \\
\text { technocrats }\end{array}$ & $\begin{array}{l}\text { Stellenbosch- } \\
\text { South Africa }\end{array}$ & $\begin{array}{l}\text { A } 14.2 \mathrm{~m}^{2} \text { improved Shack } \\
\text { dwelling with a fire-retardant } \\
\text { insulation, a solar panel, and } \\
\text { a gutter }\end{array}$ & $\begin{array}{l}\text { - iShack as an infrastructure } \\
\text { for solving housing, energy } \\
\text { and sanitation challenges, } \\
\text { and shaping which futures } \\
\text { are considered desirable or } \\
\text { even possible for urban } \\
\text { dwellers in informal } \\
\text { settlements. }\end{array}$ \\
\hline $\begin{array}{l}\text { Power over } \\
\text { locally- } \\
\text { embedded } \\
\text { knowledge }\end{array}$ & $\begin{array}{l}\text { Local community } \\
\text { groups (formal } \\
\text { and informal) and } \\
\text { city residents }\end{array}$ & $\begin{array}{l}\text { Durban- } \\
\text { South Africa }\end{array}$ & $\begin{array}{l}\text { A localized coastal } \\
\text { vulnerability assessment, } \\
\text { social, economic, built } \\
\text { environment, and physical } \\
\text { characteristics were } \\
\text { integrated into a single tool }\end{array}$ & $\begin{array}{l}\text { - An integrated coastal } \\
\text { vulnerability assessment tool } \\
\text { as the legitimate figure to } \\
\text { judge which measure/ } \\
\text { indicators are relevant for } \\
\text { science and valuable to } \\
\text { policy-makers and city } \\
\text { residents }\end{array}$ \\
\hline
\end{tabular}

background and this allowed statutory power and the power of locally-embedded knowledge to influence the nature and content of the coastal vulnerability index. Notwithstanding the contextual issues, boundary objects across the case studies provide a shared understanding of the relationships and interdependencies among transient networks of actors who can bring about the diffusion of alternative solutions through interventions that are beyond the purview of formal government service delivery. For instance, it is within the shadows of formal grid electricity and waste management services, that city residents in Kampala city exercise their power to innovate and create knowledge sharing networks to transform behaviors and lifestyles in a more sustainable direction, while improving health and livelihood prospects. This means that the interdependencies between scientific and societal knowledge in co-producing knowledge, is not just, or even a socio-technical process of uncovering what it means to experiment sustainable solutions. Rather it calls for ingenuity, imaginaries and interruption of power relations amongst the actors involved, who in the cases presented, used the boundary objects to aggregate diverse perspectives on pathways to urban sustainability.

\section{Discussion}

The paper articulates conceptually dynamic forms of power that manifested across the projects and the usefulness of boundary objects in navigating such forms of power within the context of transformations to sustainable cities. The paper further provides empirically grounded and broad reflections on the sources of power that shape sciencesocietal interactions in co-producing knowledge. Such sources of power are tied to relational, material or ideational aspects of co-producing knowledge. Material sources of power are for instance the financial means that actors in Stellenbosch used to demonstrate the design and joint learning effects of pilot solar electrification, as an 
interconnected infrastructure for housing, energy and sanitation, which built bridges across different actors for sustainability in informal settlements. The iShack as a material boundary object in the co-production process, had the potential to give actors not only direct decision-making power and setting the research agenda, but also a structural context for equipping policy-makers with statutory power.

Ideational sources of power derive from social constructs such as ideas, values, and norms (Avelino and Rotmans 2011; Purdy 2012; Fuchs et al. 2016). Ideational sources of power are exemplified in the case of Durban, where socially-constructed perceptions of vulnerability by city residents gained a legitimate position in the coproduction process, as sources of knowledge on how to measure loss of property, joblessness and the social disengagements brought about by climate hazards. In the case of Kampala, mutuality exists amongst relational, material and ideational sources of power. The legitimacy of knowledge on the cleanness of energy briquettes when compared to charcoal, constitutes a crucial source of ideational power that is exercised in a context where briquette-making enterprises envisage the financial gains of scaling up, through a myriad of social relations that exist in the local community. Briquette-makers have the socially acknowledged right to make judgments, take decisions, or conduct actions that give chance to the much needed policy-shift, from landfill to recycling and re-use of waste, within the wider institutional context of KCCA. This means that power dynamics in co-producing knowledge are context-sensitive and no single framework can be used to examine power exhaustively.

\section{Conclusion}

Co-producing knowledge is often cast as a novel set of methods that can be downscaled to create equitable spaces for collaboration between different stakeholders. However, the peculiar features of cities in Africa, with regard to the agile nature of informal settlements, socio-demographic structures, the multiplicity of ecologies, cultural diversity and the historical drivers and scale of urbanization, bring bear the fact that the principles of co-producing knowledge vary according to contextual accounts. By illuminating how place-based, formal and informal partnerships, across different disciplines and sectors, were formed and sustained, the paper anchors the co-production of knowledge in local contexts that re-position groups, whose voices and aspirations are usually silenced or formally excluded in global processes that seek to steer the pace and confront the effects of rapid urbanization. Co-producing knowledge is vital to grasping problems, unlocking the resourcefulness and agency of local communities, through the use of boundary objects that support actors to cross the conventional boundaries between science, policy and society. However, the conception of transformations to sustainable cities at local scale, is contested and multifaceted in nature, in addition to the unanticipated, often chaotic and complex nature of global challenges, like climate change, inequality, disease outbreaks and digital disruptions, through which the concept is often applied in science and policy circles. Nonetheless, nuanced means to coproducing knowledge can bring about new relational patterns amongst stakeholders, thus leading to interactions that can un-discipline science in envisioning, negotiating, learning and experimenting transformations to sustainable cities. 


\section{Abbreviations}

iShack: Improved Shack; KCCA: Kampala Capital City Authority; LoNSEK: Localized Norms on Sustainable Energy in Kampala; USD: United States Dollars

\section{Acknowledgments}

We thank the Sustainability Institute of Stellenbosch University in South Africa, the Urban Action Lab of Makerere University in Uganda, and eThekwini Municipality in Durban for granting access to the profiles of the projects presented in this paper. The reviewer comments were instrumental in improving the quality and brevity of the content.

\section{Authors' contributions}

BK conceived the framing of the paper and assisted JW in the design, gathering, analysis and interpretation of data for this piece of work. PM, SL and SO revised the work critically for important intellectual content. The authors read and approved the final manuscript.

\section{Funding}

Research for this paper was funded by the International Science Council (ISC), under a global research programme known as Leading Integrated Research on Agenda 2030 (LIRA 2030), with support from the Swedish International Development Agency (SIDA), GRANT NUMBER: LIRA 2030-GR10/18. The manuscript review workshops were funded by the AXA Research Fund, under the Kampala-based project called a new understanding of urban sustainability pathways in Africa, with SL as the chair.

\section{Availability of data and materials}

Any data that support the findings of this study are included within the article.

\section{Competing interests}

The authors have no competing interests to declare.

\section{Author details}

${ }^{1}$ Urban Action Lab of Makerere University Uganda, Department of Geography, Geo-informatics and Climatic Sciences, College of Agricultural and Environmental Sciences, University Road, CHUSS Building, South Wing Ground Floor, P.O Box 7062, Kampala, Uganda. ²Department of Geography and Environmental Studies, University of Nairobi, Nairobi, Kenya.

Received: 4 May 2019 Accepted: 20 January 2021

Published online: 30 January 2021

\section{References}

Akl EA, Khamis AM. The intersections of industry with the health research enterprise. Health Res Policy Syst. 2019;17(1):53. https://doi.org/10.1186/s12961-019-0457-7.

Avelino F, Rotmans J. Power in transition. Empowering Discourses on Sustainability Transitions. Erasmus Universiteit Rotterdam; 2011.

Bai X, Roberts B, Chen J. Urban sustainability experiments in Asia: patterns and pathways. Environ Sci Policy. 2010;13:312-25. https://doi.org/10.1016/j.envsci.2010.03.011.

Beier P, Hansen L, Helbrecht L, Behar D. A how-to guide for coproduction of actionable science. Conserv Lett. 2017;10(3): 288-96.

Bremer S, Wardekker A, Dessai S, Sobolowski S, Slaattelid R, van der Sluijs J. Toward a multi-faceted conception of coproduction of climate services. Climate Services. 2019;13:42-50. https://doi.org/10.1016/j.cliser.2019.01.003.

Brown JS, Duguid P. Knowledge and organization: a social-practice perspective. Organ Sci. 2001;12(2):198-213.

Buyana K. Keeping the doors open: experimenting science-policy-practice interfaces in Africa for sustainable urban development. J Housing Built Environ. 2019;35:539-54. https://doi.org/10.1007/s10901-019-09699-3.

Buyana K, Lwasa S, Tugume D, Mukwaya P, Walubwa J, Owuor S, et al. Pathways for resilience to climate change in African cities. Environ Res Lett. 2020;15(7). https://doi.org/10.1088/1748-9326/ab7951.

Castán Broto V, Neves Alves S. Intersectionality challenges for the co-production of urban services: notes for a theoretical and methodological agenda. Environ Urban. 2018;30(2):367-86. https://doi.org/10.1177/2F0956247818790208.

DeLorme DE, Kidwell D, Hagen SC, Stephens SH. Developing and managing transdisciplinary and transformative research on the coastal dynamics of sea level rise: experiences and lessons learned. Earth's Future. 2016:4(5):194-209.

Dentoni D, Bitzer V. The role (s) of universities in dealing with global wicked problems through multi-stakeholder initiatives. J Clean Prod. 2015;106:68-78. https://doi.org/10.1016/j.jclepro.2014.09.050.

Durban Environmental Planning and Climate Protection Department. Durban: a climate for change -transforming Africa's future; 2012. A selection of Durban's Climate Change Projects

Ethekwini Municipality. "Draft economic development and job creation strategy 2012", report published by the economic development and investment promotion unit. Durban: eThekwini Municipality; 2012. p. 54.

Fritz L, Binder CR. Whose knowledge, whose values? An empirical analysis of power in transdisciplinary sustainability research Eur J Futures Res. 2020;8(1):1-21. https://doi.org/10.1186/s40309-020-0161-4.

Fuchs D, Di Giulio A, Glaab K, Lorek S, Maniates M, Princen T, et al. Power: the missing element in sustainable consumption and absolute reductions research and action. J Clean Prod. 2016;132:298-307. https://doi.org/10.1016/ j.jclepro.2015.02.006.

Future Earth. (2016). Future Earth knowledge action networks. Accessed 3 Jan 2019 from http://futureearth.org/futureearth-urban 
Gillis D, Nelson J, Driscoll B, Hodgins K, Fraser E, Jacobs S. Interdisciplinary and transdisciplinary research and education in Canada: a review and suggested framework. Collected Essays Learning Teaching. 2017;10:203-22.

Gulyani S, Bassett EM. Retrieving the baby from the bathwater: slum upgrading in sub-Saharan Africa. Environ Planning C: Gov Policy. 2007;25(4):486-515. https://doi.org/10.1068/2Fc4p.

Hadorn GH, Biber-Klemm S, Grossenbacher-Mansuy W, Hoffmann-Riem H, Joye D, Pohl C, et al., editors. Handbook of transdisciplinary research (Vol. 10). Dordrecht: Springer; 2008. p. 978-1.

Jones BG. 'Bankable slums': the global politics of slum upgrading. Third World Q. 2012;33(5):769-89. https://doi.org/10.1080/ 01436597.2012 .679027$.

Kampala Capital City Authority, KCCA (2018). Kampala Fecal Sludge Management Project: Leveraging FSM to close the Urban Sanitation Loop in Kampala. Accessed on 23 Jan 2019 from: https://kcca.go.ug/uDocs/Leveraging\%20FSM\%20to\%2 oClose\%20the\%20Urban\%20Sanitation\%20Loop\%20in\%20Kampala.pdf

Kasperson RE, Berberian M, editors. Integrating science and policy: vulnerability and resilience in global environmental change. New York: Earthscan; 2011.

Kemp SP, Nurius PS. Preparing emerging doctoral scholars for transdisciplinary research: a developmental approach. J Teach Soc Work. 2015;35(1-2):131-50.

Lang D, Wiek A, Bergmann M, Stauffacher M, Martens P, Moll P, et al. Transdisciplinary research in sustainability science: practice, principles, and challenges. Sustain Sci. 2012;7(1):25-43.

Loorbach D, Frantzeskaki N, Avelino F. Sustainability transitions research: transforming science and practice for societal change. Annu Rev Env Resour. 2017;42:599-626.

Lotz-Sisitka H, Ali MB, Mphepo G, Chaves M, Macintyre T, Pesanayi T, et al. Co-designing research on transgressive learning in times of climate change. Curr Opin Environ Sustain. 2016;20:50-5.

Matthews R, Papoulias C. Toward co-productive learning? The exchange network as experimental space. Front Sociol. 2019;4:36.

Meylan G, Haupt M, Duygan M, Hellweg S, Michael S. Linking energy scenarios and waste storylines for prospective environmental assessment of waste management systems. Waste Manag. 2018:81:11-21.

Montana J. Co-production in action: perceiving power in the organisational dimensions of a global biodiversity expert process. Sustain Sci. 2019;14(6):1581-91.

Mori K, Fujii T, Yamashita T, Mimura Y, Uchiyama Y, Hayashi K. Visualization of a City sustainability index (CSI): towards transdisciplinary approaches involving multiple stakeholders. Sustainability. 2015;7(9):12402-24. https:/doi.org/10.3390/su70912402.

Mukwaya PI. Urban adaptation to energy insecurity in Uganda. Curr Urban Stud. 2016;4(01):69. https://doi.org/10.4236/cus.2016.41006.

Muzondi L. Urban development planning for sustainability: urbanization and informal settlements in a democratic South Africa. Mediterr J Soc Sci. 2014;5(14):641.

Nel JL, Roux DJ, Driver A, Hill L, Maherry AC, Snaddon K, et al. Knowledge co-production and boundary work to promote implementation of conservation plans. Conserv Biol. 2016;30(1):176-88.

Okello C, Pindozzi S, Faugno S, Boccia L. Development of bioenergy technologies in Uganda: a review of progress. Renew Sustain Energy Rev. 2013;18:55-63. https://doi.org/10.1016/j.rser.2012.10.004.

Oswick C, Robertson M. Boundary objects reconsidered: from bridges and anchors to barricades and mazes. J Chang Manag. 2009;9(2):179-93. https://doi.org/10.1080/14697010902879137.

Partzsch L, Fuchs D. Philanthropy: power with in international relations. J Political Power. 2012;5:359-76. https://doi.org/10. 1080/2158379X.2012.735114.

Pohl C, Krütli P, Stauffacher M. Ten reflective steps for rendering research societally relevant. GAIA-Ecol Perspect Sci Soc. 2017; 26(1):43-51. https://doi.org/10.14512/gaia.26.1.10.

Purdy JM. A framework for assessing power in collaborative governance processes. Public Adm Rev. 2012;72:409-17. https:// doi.org/10.1111/j.1540-6210.2011.02525.x.

Rodríguez LF, Marshall A-M, Cotton D, Koelsch R, Koziel J, Meyer D, et al. The development of the INFEWS-ER: a virtual resource Center for Transdisciplinary Graduate Student Training at the nexus of food, energy, and water. Front Environ Sci. 2019;7:38. https://doi.org/10.3389/fenvs.2019.00038.

Safford HD, Sawyer SC, Kocher SD, Hiers JK, Cross M. Linking knowledge to action: the role of boundary spanners in translating ecology. Front Ecol Environ. 2017;15(10):560-8.

Samoff J. Institutionalizing international influence. Safundi J South Afr Am Comparat Stud. 2003;4(1):1-35. https://doi.org/10. 1080/17533170300404104

Sapsed J, Salter A. Postcards from the edge: local communities, global programs and boundary objects. Organ Stud. 2004; 25(9):1515-34. https://doi.org/10.1177/2F0170840604047998.

Scholz W, Spoerri A, Lang D. Problem structuring for transitions: the case of Swiss waste management. Futures. 2009:41:17181. https://doi.org/10.1016/j.futures.2008.09.013.

Seidl R, Brand S, Stauffacher M, Krutli P, Le QB, Sporri A, et al. Science with society in the anthropocene. Ambio. 2013;4:25-12. https://doi.org/10.1007/s13280-012-0363-5.

Snilstveit B, Oliver S, Vojtkova M. Narrative approaches to systematic review and synthesis of evidence for international development policy and practice. J Dev Effectiveness. 2012;4(3):409-29.

Star SL, Griesemer JR. Institutional ecology, translations' and boundary objects: amateurs and professionals in Berkeley's Museum of Vertebrate Zoology, 1907-39. Soc Stud Sci. 1989;19(3):387-420.

Stellenbosch Municipality. (2012). Enkanini (Kayamandi) household enumeration report. http://sasdialliance.org.za/wpcontent/uploads/docs/reports/Enumerations/Enkanini\%20Final\%20Report.pdf

Stolarski MJ, Szczukowski S, Tworkowski J, Krzyżaniak M, Gulczyński P, Mleczek M. Comparison of quality and production cost of briquettes made from agricultural and forest origin biomass. Renew Energy. 2013;57:20-6. https://doi.org/10.1016/j. renene.2013.01.005

Teare G, Taks M. Extending the scoping review framework: a guide for interdisciplinary researchers. Int I Soc Res Methodol. 2020;23(3):311-5. https://doi.org/10.1080/13645579.2019.1696092.

Turnhout E, Metze T, Wyborn C, Klenk N, Louder E. The politics of co-production: participation, power, and transformation. Curr Opin Environ Sustain. 2020;42:15-21. https://doi.org/10.1016/j.cosust.2019.11.009. 
Valley W, Wittman H, Jordan N, Ahmed S, Galt R. An emerging signature pedagogy for sustainable food systems education. Renewable Agric Food Syst. 2018;33(5):467-80.

Van Breda J, Swilling M. The guiding logics and principles for designing emergent transdisciplinary research processes: learning experiences and reflections from a transdisciplinary urban case study in Enkanini informal settlement. South Africa Sustain Sci. 2018;14(3):823-41.

Van der Hel S. New science for global sustainability? The institutionalization of knowledge co-production in future earth. Environ Sci Policy. 2016;61:165-75. https://doi.org/10.1016/j.envsci.2016.03.012.

Volken SP, Xexakis G, Trutnevyte E. Perspectives of informed citizen panel on low-carbon electricity portfolios in Switzerland and longer-term evaluation of informational materials. Environ Sci Technol. 2018;52(20):11478-89.

Vukomanovic J, Skrip MM, Meentemeyer RK. Making it spatial makes it personal: engaging stakeholders with geospatial participatory modeling. Land. 2019;8(2):38.

Wittmayer JM, Schäpke N. Action, research and participation: roles of researchers in sustainability transitions. Sustain Sci. 2014 9(4):483-96. https://doi.org/10.1007/s11625-014-0258-4.

Wyborn C, Datta A, Montana J, Ryan M, Leith P, Chaffin B, et al. Co-producing sustainability: reordering the governance of science, policy, and practice. Annu Rev Env Resour. 2019;44:319-46. https:/doi.org/10.1146/annurev-environ-101718-033103.

Yaman S, Şahan M, Haykiri-Acma H, Şeşen K, Küçükbayrak S. Production of fuel briquettes from olive refuse and paper mil waste. Fuel Process Technol. 2000;68(1):23-31. https://doi.org/10.1016/S0378-3820(00)00111-9.

Ziblim A, Sumeghy MG, Cartwright A. The dynamics of informal settlements upgrading in South Africa. Habitat Int. 2013;37: 316-34.

Ziervogel G, Archer van Garderen E, Price P. Strengthening the knowledge-policy interface through co-production of a climate adaptation plan: leveraging opportunities in Bergrivier municipality, South Africa. Environ Urban. 2016;28(2):45574. https://doi.org/10.1177/2F0956247816647340.

\section{Publisher's Note}

Springer Nature remains neutral with regard to jurisdictional claims in published maps and institutional affiliations.

\section{Ready to submit your research? Choose BMC and benefit from}

- fast, convenient online submission

- thorough peer review by experienced researchers in your field

- rapid publication on acceptance

- support for research data, including large and complex data types

- gold Open Access which fosters wider collaboration and increased citations

- maximum visibility for your research: over $100 \mathrm{M}$ website views per year

At $B M C$, research is always in progress. 